GRASAS Y ACEITES 65 (1)

January-March 2014, e002

ISSN-L: 0017-3495

doi: http://dx.doi.org/10.3989/gya.037213

\title{
Texture and antioxidant evolution of naturally green table olives as affected by different sodium chloride brine concentrations
}

\author{
C. Fadda, A. Del Caro, A.M. Sanguinetti and A. Piga \\ Dipartimento di Agraria, Viale Italia 39/A, 07100 Sassari, Italy \\ ${ }^{\star}$ corresponding author: pigaa@uniss.it
}

Submitted: 25 February 2013; Accepted: 9 September 2013; Published on line: 13/02/2014

SUMMARY: The results on the evolution of the texture and antioxidant activity during the processing of naturally fermented green olives are reported in the present study. The olives were brined with two different $\mathrm{NaCl}$ concentrations, 4 and 7\%. A puncture test and a texture profile analysis (TPA) test were carried out to evaluate texture, while the antioxidant activity was assessed in consideration of the loss of absorbance of a stable radical upon reaction with a polyphenolic olive extract. The puncture test revealed both an increase and decrease in peel and flesh hardness, respectively. The olives processed with $7 \% \mathrm{NaCl}$ concentration showed higher peel hardness than olives brined with $4 \%$ salt. The texture profile analysis did not reveal any difference between the two salt concentrations used, but showed a decrease in the value of all parameters after 30 days of brining. The antioxidant activity of the polyphenolic extract decreased significantly during processing, with a major loss after the first 30 days of processing and was higher in the $7 \%$ brined olives, than the sample treated with $4 \% \mathrm{NaCl}$.

KEYWORDS: Antioxidant activity; Natural Fermentation; Sensory analysis; Texture; Texture profile analysis; Tonda di Cagliari

RESUMEN: Evolución de la textura y capacidad antioxidante de aceitunas de mesa procesadas al natural con diferentes concentraciones de cloruro de sodio. En este trabajo se presentan los resultados sobre la evolución de la textura y la actividad antioxidante durante el proceso de fermentación natural de las aceitunas verdes. Los frutos se colocaron en salmueras con dos concentraciones de $\mathrm{NaCl}$ del $4 \%$ y $7 \%$. Se evaluó la textura mediante ensayo de perforación y mediante análisis de perfil de textura (TPA), mientras que la actividad antioxidante se evaluó considerando la pérdida de absorbancia de un radical estable tras la reacción con un extracto polifenólico de las aceitunas. El ensayo de perforación reveló un aumento de la dureza de la piel y una reducción en la dureza de la pulpa. Las aceitunas procesadas con una concentración de $\mathrm{NaCl}$ del 7\% mostraron una dureza mayor que aquellas tratadas con sal al 4\%. El análisis del perfil de la textura no reveló diferencias entre las dos concentraciones usadas de sal, pero mostró una disminución en el valor de todos los parámetros después del primer mes de salmuera. La actividad antioxidante del extracto polifenólico disminuyó significativamente durante el tratamiento, con una pérdida importante después de los primeros 30 días de tratamiento y fue más alto en las aceitunas del 7\% en salmuera respecto a las muestras tratadas con el $4 \%$ de $\mathrm{NaCl}$.

PALABRAS CLAVE: Actividad antioxidante; Análisis de perfil de textura; Análisis sensorial; Fermentación natural; Textura; Tonda di Cagliari

Citation/Cómo citar este artículo: Fadda C, Del Caro A, Sanguinetti AM, Piga A. 2014. Texture and antioxidant evolution of naturally green table olives as affected by different sodium chloride brine concentrations. Grasas Aceites 65 (1): e002. doi: http://dx.doi.org/10.3989/gya.037213

Copyright: (C) 2014 CSIC. This is an open-access article distributed under the terms of the Creative Commons Attribution-Non Commercial (by-nc) Spain 3.0 Licence. 


\section{INTRODUCTION}

According to International Olive Oil Council (2012), table olives represent about $10 \%$ of the total olive processing industry. Table olive processing includes the removal of the bitter taste of olives and fermentation. The main commercial preparations are the green Spanish style (green olives alkali treated and fermented), the Greek style (black olives naturally fermented) and the Californian style (turning color or black olives alkali treated and oxidized). In addition to these, there are many other processing systems in the world and each country has its specialties. Italy, for example, produces about $20 \%$ of naturally fermented green olives, which are prepared by directly placing fruits in brine, as reported by the International Olive Oil Council (2004). This type of olives is partially debittered by diffusion of the bitter polyphenolic compounds from the flesh to the brine over a time ranging from 5 to 8 months. Fermentation is mainly carried out by yeasts (BrenesBalbuena et al., 1986; Farris et al., 1989; Marquina et al., 1992; Borcackli et al., 1993), although lactobacilli growth has been reported (Durán-Quintana and González-Cancho, 1973; González-Cancho et al., 1975; Abriouel et al., 2012). The presence of lactobacilli is, however, very sporadic and depends on the release of toxic secoiridoid derivatives from the flesh into the brine (Medina et al., 2010). The chemical-physical evolution of brines and olives during processing has been deeply investigated in our lab and by other authors (Piga and Agabbio, 2003; Poiana and Romeo, 2006; Romeo et al., 2012), but no study on intact green olives has been undertaken so far concerning the instrumental measurements of texture, which is one of the attributes that most affects the consumer acceptance of table olives and may be strongly influenced during processing. The only paper focuses on cracked green olives (Bautista-Gallego et al., 2011). Texture loss is mainly caused by the enzymatic activity of microorganisms that may result in softening, primarily due to the degradation of pectic substances of the cell wall and middle lamella (Araujo et al., 1994; Jimenez et al., 1997; Fernández-Bolaños et al., 2001). Factors influencing the activity of hydrolytic enzymes are the $\mathrm{pH}$ and $\mathrm{NaCl}$ concentrations of brines (Fernández-Bolaños et al., 2001).

An instrumental texture analysis has been applied to Spanish style olives (Jimenez et al., 1997; Morales-Sillero et al., 2008; Rejano-Navarro et al., 2008), Greek style olives (Kanavouras et al., 2005; Tassou et al., 2007; Lanza et al., 2010; Romeo et al., 2012), Californian style (Georget et al., 2003; Romeo et al., 2012) and other styles (Marsilio et al., 2000; Arroyo-López et al., 2007; Romeo et al., 2012). In a recent paper Romeo et al. (2012) evaluated the effect of post-processing treatments on the texture of fermented green olives, but no study has been undertaken so far on naturally fermented green table olives. Recently, due to the association of sodium intake with hypertension, different authors have reported on the reduction or partial substitution of sodium chloride in brines (BautistaGallego et al., 2010; Bautista-Gallego et al., 2011; Panagou et al., 2011; Moreno-Baquero et al., 2012; Rodríguez-Gómez et al., 2012). In this context we demonstrated that it is possible to successfully process green table olives in the natural style using a low sodium chloride brine concentration (2-4\%), assuring that the brines are acidified at $\mathrm{pH} 4.0$ (Piga and Agabbio, 2003).

As stated before, debittering is essential to making table olives edible. Whatever the method used, a significant loss in polyphenols occurs during the various processing steps and if we consider that polyphenols not only affect the sensory properties, but also the health promoting capacity, we can understand that differences in health properties can be found among the processing technologies used. Therefore, the health promoting capacity can be indirectly evaluated by measuring the in vitro antioxidant activity, as reported for many foods, including table olives (Pereira et al., 2006; Sousa et al., 2008; Malheiro et al., 2011).

For the above cited reason we investigated the evolution of the texture and antioxidant activity of the polyphenolic extract during the processing of naturally fermented green olives brined at two different sodium chloride brine concentrations. The chemical-physical parameters of brine and olives were also determined.

\section{MATERIALS AND METHODS}

\subsection{Plant material}

Fruits of the "Tonda di Cagliari" cultivar were handpicked from an irrigated orchard in north Sardinia in the last decade of October at a green ripe stage and soon transferred at our lab for processing. The cultivar has been chosen because it proved to be very suitable for this kind of preparation in previous trials carried out at our lab. Selection before brining was done by discarding olives with blemishes, cuts and insect punctures as well as under or over ripe fruits. Calibration was performed with laboratory callipers and olives ranging from 17 to $21 \mathrm{~mm}$ in transversal diameter were considered. Replicates of $12 \mathrm{~kg}$ were prepared for further processing.

\subsection{Processing}

After careful washing with tap water to remove field dust, the olives were transferred to $20 \mathrm{~L}$ previously sterilized plastic containers and then processed by brining, which was carried out by preparing sterile 4 and $7 \%(\mathrm{w} / \mathrm{w})$ sodium chloride solutions which were 
used to completely fill the containers which were finally closed after a perforated cap was placed between the olives and the top part of the container to submerge the olives in the brine. The $\mathrm{pH}$ of the brine was previously adjusted to 4 with lactic acid to prevent the growth of gas pockets producing Enterobacteriaceae (Garrido-Fernández et al., 1997). Three containers per sodium chloride concentration were used. The containers were kept at $20^{\circ} \mathrm{C}$. The sodium chloride concentration and $\mathrm{pH}$ were inspected at $5,10,15,20$, 30,45 and 60 days and afterwards at monthly intervals up to 180 days in order to make corrections when necessary. The growth of aerobic oxidative yeasts and moulds on the brine surface was avoided by adjusting the brine level with freshly prepared sterile brine. We stopped determinations at 180 days as most of the chemical parameters had reached a steady state and the olives were ready for consumption as revealed by a sensory test.

\subsection{Chemical-physical analysis}

Triplicate analyses of the following parameters for each container were carried out in the brine: $\mathrm{pH}$ with a glass electrode, free acidity (g of lactic acid per $100 \mathrm{~mL}$ of brine), sodium chloride (g $100 \mathrm{~mL}^{-1}$ ), reducing sugars (g $100 \mathrm{~mL}^{-1}$ of brine) and phenols (mg gallic acid $100 \mathrm{~g}^{-1}$ of brine), according to Garrido-Fernández et al. (1997). The free acidity value obtained was corrected by subtracting the initial and following amounts of lactic acid added. Determinations on homogenised flesh were $\mathrm{pH}$, sodium chloride, reducing sugars and total phenols. Total phenols were extracted according to Amiot et al. (1986) and determined as described by Garrido-Fernández et al. (1997). Sodium chloride was determined as for brines after extraction from flesh: in brief, $10 \mathrm{~g}$ of flesh were diluted with $30 \mathrm{~mL}$ of water and homogenized with an Ultra Turrax for 60 seconds, the resulting slurry was brought to $50 \mathrm{~mL}$ and centrifuged for $10 \mathrm{~min}$ at $5000 \mathrm{rpm}$. An aliquot of $1 \mathrm{~mL}$ was taken to make the analysis following the method proposed by Garrido-Fernández et al. (1997). Reducing sugars and polyphenol analysis in brine and flesh and sodium chloride in flesh were made at $0,30,60,120$ and 180 days.

\subsection{Antioxidant activity}

The antioxidant activity was determined on the polyphenolic extract using the DPPH stable radical, following the method proposed by Ramadan and Morsel (2006). Briefly, $50 \mu \mathrm{L}$ of methanolic extract were dissolved in $1950 \mu \mathrm{L}$ of toluene and after vortexing for 1 minute an amount of $200 \mu \mathrm{L}$ was made to react in a $1 \mathrm{~cm}$ path cuvette at $22^{\circ} \mathrm{C}$ under continuous stirring with $1.8 \mathrm{~mL}$ of a $10^{-4} \mathrm{M}$ toluenic solution of DPPH. The decrease in absorbance at $515 \mathrm{~nm}$ was taken at $1,5,15,30$ and 60 minutes against a blank of pure toluene using a spectrophotometer (mod. 8453, Hewlett-Packard, Palo Alto, California). The antioxidant activity was considered as the difference in absorbance between each sample and a toluenic DPPH solution without the sample (control) and calculated as percentage of inhibition according to the following equation:

$\%$ of inhibition $=\frac{\text { absorbance of control }- \text { absorbance of sample } \times 100}{\text { absorbance of control }}$

\subsection{Texture analysis}

Texture analyses in fresh olives and changes during processing were monitored with a texture analyzer (mod. TA-XT2, Stable Microsystems, Surrey, UK) fitted with a 5 or $50 \mathrm{~kg}$ load cell. The Texture Expert program version 1.21 was used for processing data. A puncture test and a Texture Profile Analysis (TPA) were performed using twenty olives for each determination and brine concentration.

For the puncture test the olives were placed on an HDP/90 platform and punctured in the lateral face. The test was performed using an SMS P/2 needle probe and a $5 \mathrm{~kg}$ load cell. The test speed was $1.0 \mathrm{~mm} \mathrm{~s}^{-1}$ and the penetration depth was limited to $3 \mathrm{~mm}$. The force-time curve was graphically acquired and elaborated. Three parameters were taken into account to evaluate the evolution of texture during fermentation (Figure 1): the olive peel break force (yield point), as the maximum force (N) reached during puncturing (F1); the hardness of the peel, as the area under the curve $\left(\mathrm{N} \mathrm{mm}^{-1}\right)$ up to the yield point (from point 0 to $\mathrm{F} 1$, that is $\mathrm{A} 1$ ); the hardness of the flesh (A2), as the area $\left(\mathrm{N} \mathrm{mm}^{-1}\right)$ calculated starting from the point of minimum force after the probe penetration (F2) and the maximum force $(\mathrm{F} 3)$.

The TPA was carried out on the lateral face of whole olives in compression mode using an SMSP/75 plate. The probe speed was set at $0.5 \mathrm{~mm} \mathrm{sec} \mathrm{s}^{-1}$, time between compressions was $5 \mathrm{sec}$ and the test was stopped at $15 \%$ deformation after the auto triggering signal. A $50 \mathrm{~kg}$ load cell was used. Hardness, cohesiveness, gumminess, chewiness and springiness, as reported by Szczesniak (1963) and Friedman et al. (1963), were evaluated and calculated by the instrument software. Texture determinations were carried out at $0,30,60,120$ and 180 days.

\subsection{Sensory evaluation}

The table olives were assessed at the end of brining (180 days) by 30 untrained judges who were asked to express their preference on the two samples. We performed a paired preference test as reported by Stone and Sidel (2004a). 


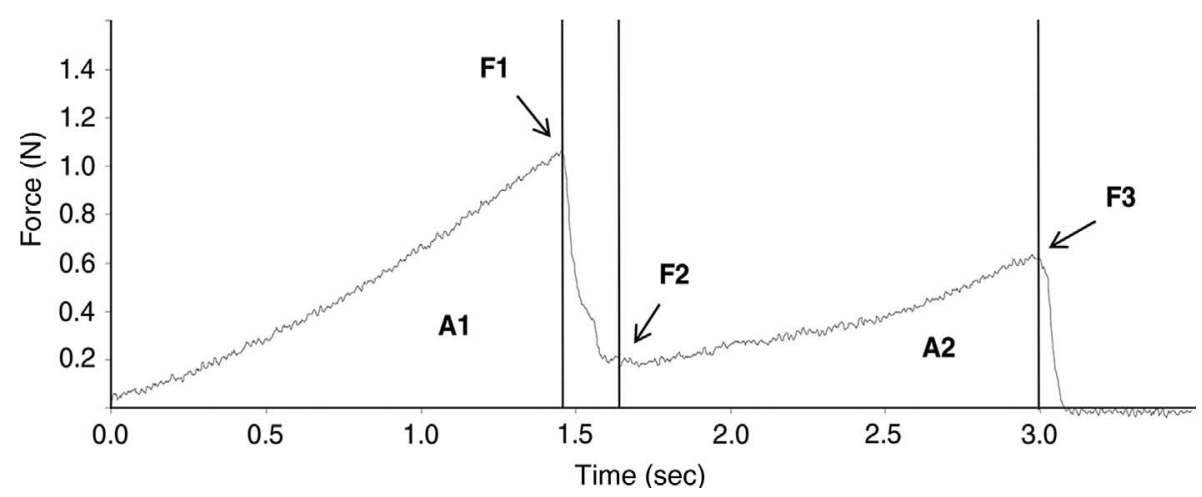

FiguRE 1. Representative graph of a puncture test.

\subsection{Statistical analysis}

Data on reducing sugars and polyphenol content on brines and olives and on the $\mathrm{NaCl}$ contents in the olives were subjected to one-way analysis of variance (ANOVA), with sodium chloride concentration as the group variable. Texture and antioxidant activity data were submitted to two-way ANOVA, where the factors were the sodium chloride and the days of storage. Data on sensory analysis were evaluated using the critical values table for duo-trio test and paired preference test (Stone and Sidel, 2004b). The software Statistica 6.0 for Windows was used to process data. Means, when required, were separated according to the Tukey test, with a significance level $P \leq 0.05$.

\section{RESULTS AND DISCUSSION}

\subsection{Physicochemical changes in brines and olives}

An analysis of the chemical-physical parameters in the brines and olives were carried out mainly to check the appropriate evolution of processing and to correct, at each inspection time, $\mathrm{pH}$ and sodium chloride values. Data obtained, in fact, were as expected and as reported in the literature (Garrido-Fernández et al., 1997; Piga et al., 2001; Piga and Agabbio; 2003) (Table 1). The $\mathrm{pH}$ and sodium chloride concentration in brines showed a major shift from the fixed values during the first 60 days of processing, and after that were more stable (data not shown). The values for the corrected free acidity revealed the development of values not exceeding $0.5 \mathrm{~g}$ of lactic acid per $100 \mathrm{~mL}$ of brine, which is evidence of fermentative yeast growth and an absence of lactobacilli (data not shown). The diffusion of polyphenols and reducing sugars from the flesh into brines was noticeable and significantly higher in olives processed with a $4 \%$ sodium chloride concentration.
On the contrary and as expected, the sodium chloride content in the olives was significantly higher in the samples brined at a 7\% salt concentration.

\subsection{Texture evolution}

As a result of the penetration test, the particular structure of the olive fruits generates a particular graph which shows a progressive increasing force during penetration up to the breaking of the peel. This maximum force (F1) has already been considered as a hardness index of the peel (Romeo et al., 2012). This part of the curve looks like a type $C$ one, as reported by Bourne (1979). In addition, the area under the curve up to F1, explains the work required to break the peel and thus represents its hardness. After this yield point a sudden force loss is registered due to the penetration of the first layers of flesh, which opposes a lower resistance to probe progress, and an increasing force up to a maximum value is registered. The area between the minimum force F2 and the maximum force F3 is a good index for flesh hardness. The evolution of the structure of the peel, as revealed by the puncture test, shows significant differences between olives brined with the two $\mathrm{NaCl}$ concentrations. In fact, the peel of olives brined with $7 \% \mathrm{NaCl}$ showed higher values for the breaking force and hardness, with respect to the 4\% processed olives (Table 2). These differences were significant after 60 days (Figures 2-3). Tassou et al. (2007) did not find differences in skin strength following brining with different sodium chloride concentrations, but they worked with black olives and performed the texture analysis on a peel strip and in tension mode. The most important result, however, is that peel break force and hardness increased during brining. Romeo et al. (2012) found similar results by brining turning color "Biancolilla" olives at $12 \%$; while Georget et al. (2003) and Tassou et al. (2007) found a different behavior, but, as stated before, both the different degrees of ripening or 
Texture and antioxidant evolution of naturally green table olives as affected by different sodium chloride brine concentrations $\bullet 5$

TABLE 1. Evolution of some chemical parameters of the brines and olives of Tonda di Cagliari olives during 180 days of brining

\begin{tabular}{|c|c|c|c|c|c|c|}
\hline \multirow[b]{2}{*}{$\mathrm{NaCl}(\%)$} & \multirow[b]{2}{*}{$\begin{array}{c}\text { Sampling } \\
\text { Period (days) }\end{array}$} & \multicolumn{2}{|c|}{ Brines } & \multicolumn{3}{|c|}{ Olive flesh } \\
\hline & & $\begin{array}{c}\text { Reducing sugars } \\
(\%)\end{array}$ & $\begin{array}{c}\text { Total polyphenols } \\
\text { (mg gallic acid } \\
\left.100 \mathrm{~mL}^{-1}\right)\end{array}$ & $\begin{array}{c}\text { Sodium Chloride } \\
(\%)\end{array}$ & $\begin{array}{c}\text { Reducing sugars } \\
(\%)\end{array}$ & $\begin{array}{c}\text { Total polyphenols } \\
(\mathrm{mg} \text { gallic acid } \\
\left.100 \mathrm{~mL}^{-1}\right)\end{array}$ \\
\hline 4 & 0 & - & - & $0.12 \mathrm{a}$ & $1.88 \mathrm{a}$ & $359.2 \mathrm{a}$ \\
\hline 7 & & - & - & $0.12 \mathrm{a}$ & $1.88 \mathrm{a}$ & $359.2 \mathrm{a}$ \\
\hline 4 & 30 & $0.210 \mathrm{a}^{*}$ & $62.6 \mathrm{a}$ & $0.82 b$ & $1.68 \mathrm{a}$ & $246.1 \mathrm{~b}$ \\
\hline 7 & & $0.144 b$ & $50.9 \mathrm{~b}$ & $1.87 \mathrm{a}$ & $1.75 \mathrm{a}$ & $267.9 \mathrm{a}$ \\
\hline 4 & 60 & $0.579 \mathrm{a}$ & $92.7 \mathrm{a}$ & $1.69 \mathrm{~b}$ & $1.46 \mathrm{~b}$ & $183.4 \mathrm{~b}$ \\
\hline 7 & & $0.406 \mathrm{~b}$ & $76.4 b$ & $2.81 \mathrm{a}$ & $1.58 \mathrm{a}$ & $228.2 \mathrm{a}$ \\
\hline 4 & 120 & $0.458 \mathrm{a}$ & $110.9 \mathrm{a}$ & $2.16 \mathrm{~b}$ & $1.32 \mathrm{~b}$ & $165.9 \mathrm{~b}$ \\
\hline 7 & & $0.298 b$ & $95.5 b$ & $3.04 \mathrm{a}$ & $1.48 \mathrm{a}$ & $197.8 \mathrm{a}$ \\
\hline 4 & 180 & $0.324 \mathrm{a}$ & $135.8 \mathrm{a}$ & $2.86 \mathrm{~b}$ & $1.02 \mathrm{~b}$ & $66.5 b$ \\
\hline 7 & & $0.224 b$ & $111.6 \mathrm{~b}$ & $3.74 \mathrm{a}$ & $1.25 \mathrm{a}$ & $80.5 \mathrm{a}$ \\
\hline
\end{tabular}

*Means followed by different letters within each column and sampling period are significantly different according to the Tukey test, significance level $P \leq 0.05$.

mechanical testing may have influenced the results. This peel hardening may be explained by the fact that the peel shrivelled due to the contemporary effects of sodium chloride absorption and water loss, thus resulting in the development of a crust.

On the other hand, the different $\mathrm{NaCl}$ concentrations did not influence the flesh hardness, which, in turn, showed a significant decrease during the 180 days of brining (Table 2; Figure 4). This time, the results agree with those reported by Georget et al. (2003) and only in part with those reported by Romeo et al. (2012), and may be explained both by the loss of turgor and degradation of pectic polysaccharides during brining (Coimbra et al., 1996).

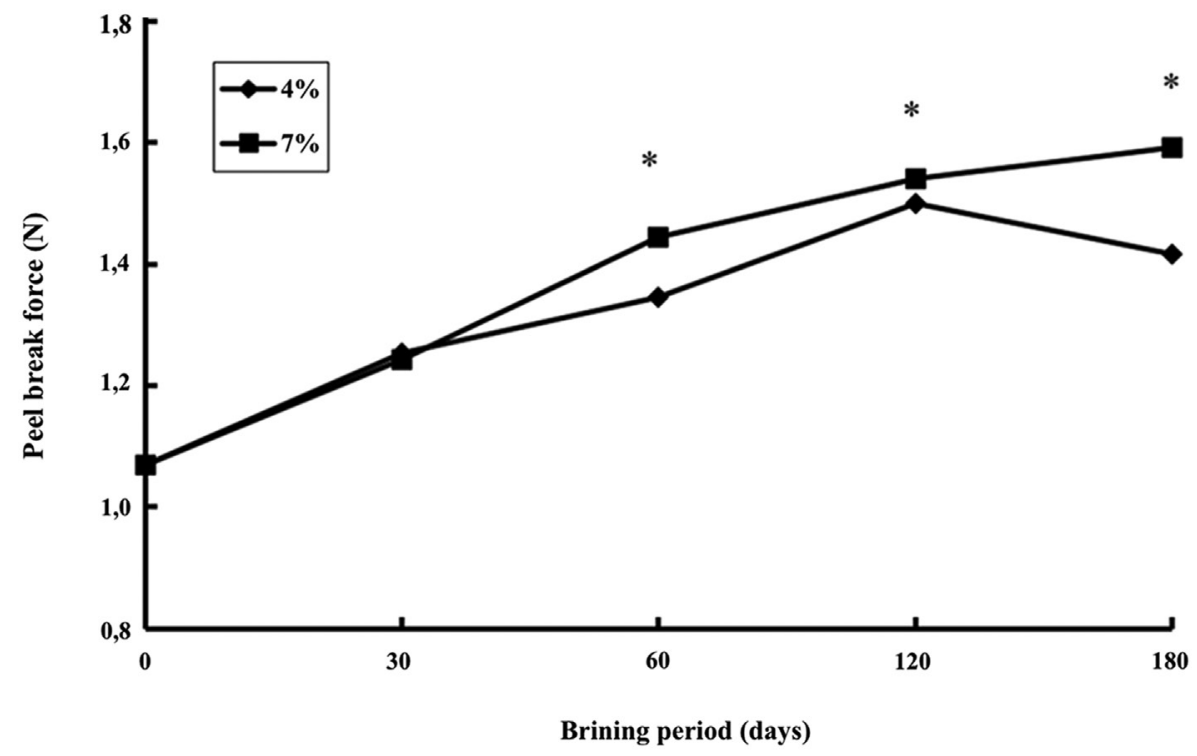

FIGURE 2. Evolution of peel break force as revealed by the puncture test during 180 days of brining of "Tonda di Cagliari" table olives. *Means statistically significant for the same period. 


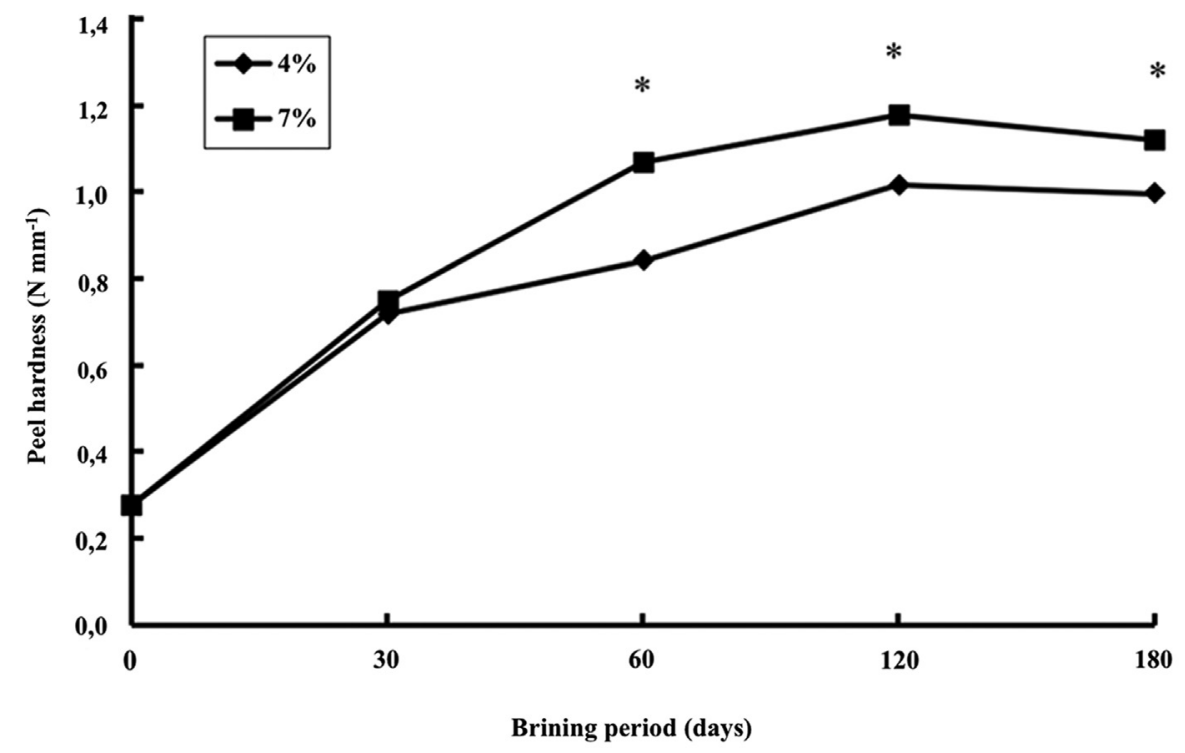

Figure 3. Evolution of peel hardness as revealed by the puncture test during 180 days of brining of "Tonda di Cagliari" table olives. *Means statistically significant for the same period.

Figure 5 shows a typical TPA graph where the two peaks of the two compression cycles can be seen. This kind of test was not able to show texture differences between the two sodium chloride concentrations used, but gave important information about the evolution of the different textural attributes during brining (Table 3). All the considered parameters, in fact, changed significantly at the first sampling time and then remained statistically constant. Hardness, which is the measurement of the maximum force of the first bite, decreased, thus indicating a softening of the flesh, as already determined from the puncture test. The same trend was noticed for cohesiveness, which accounts for the strength of the bonds making up the body of the olive flesh, and for the springiness which explains the retained elasticity of the product. The decrease in these parameters influenced the evolution of chewiness and gumminess, calculated from the above first three cited parameters. The already cited work of Coimbra et al. (1996) may explain again the loss in texture of the product.

To our knowledge, these are the very first data on texture evolution using the TPA test during the

TABLE 2. Texture* of Tonda di Cagliari olives brined olives as affected by different brine salt concentrations and storage periods

\begin{tabular}{lccc}
\hline & \multicolumn{2}{c}{ Puncture test data } \\
\cline { 2 - 4 } Source of variation & $\begin{array}{c}\text { Peel break } \\
\text { Force }(\mathbf{N})\end{array}$ & $\begin{array}{c}\text { Peel hardness } \\
\left(\mathbf{N ~ m m}^{-1}\right)\end{array}$ & $\begin{array}{c}\text { Flesh hardness } \\
\left(\mathbf{N ~ m m}^{-1}\right)\end{array}$ \\
\hline $\mathbf{N a C l}(\%)$ & & & $0.846 \mathrm{a}$ \\
$\mathbf{4}$ & $1.317 \mathrm{~b}^{\mathrm{x}}$ & $0.77 \mathrm{~b}$ & $0.871 \mathrm{a}$ \\
$\mathbf{7}$ & $1.378 \mathrm{a}$ & $0.88 \mathrm{a}$ & $1.475 \mathrm{a}$ \\
Sampling period (days) & & & $0.840 \mathrm{~b}$ \\
$\mathbf{0}$ & $1.069 \mathrm{~d}$ & $0.277 \mathrm{~d}$ & $0.731 \mathrm{c}$ \\
$\mathbf{3 0}$ & $1.248 \mathrm{c}$ & $0.733 \mathrm{c}$ & $0.599 \mathrm{~d}$ \\
$\mathbf{6 0}$ & $1.396 \mathrm{~b}$ & $0.964 \mathrm{~b}$ & $0.645 \mathrm{~cd}$ \\
$\mathbf{1 2 0}$ & $1.521 \mathrm{a}$ & $1.098 \mathrm{a}$ & $1.059 \mathrm{a}$ \\
$\mathbf{1 8 0}$ & $1.504 \mathrm{a}$ & &
\end{tabular}

*Texture has been determined with a puncture test (see the Materials and Methods section).

${ }^{\mathrm{x}}$ Data with different letters within each source of variation, thesis and column differ significantly according to the Tukey test at $P \leq 0.05$. 


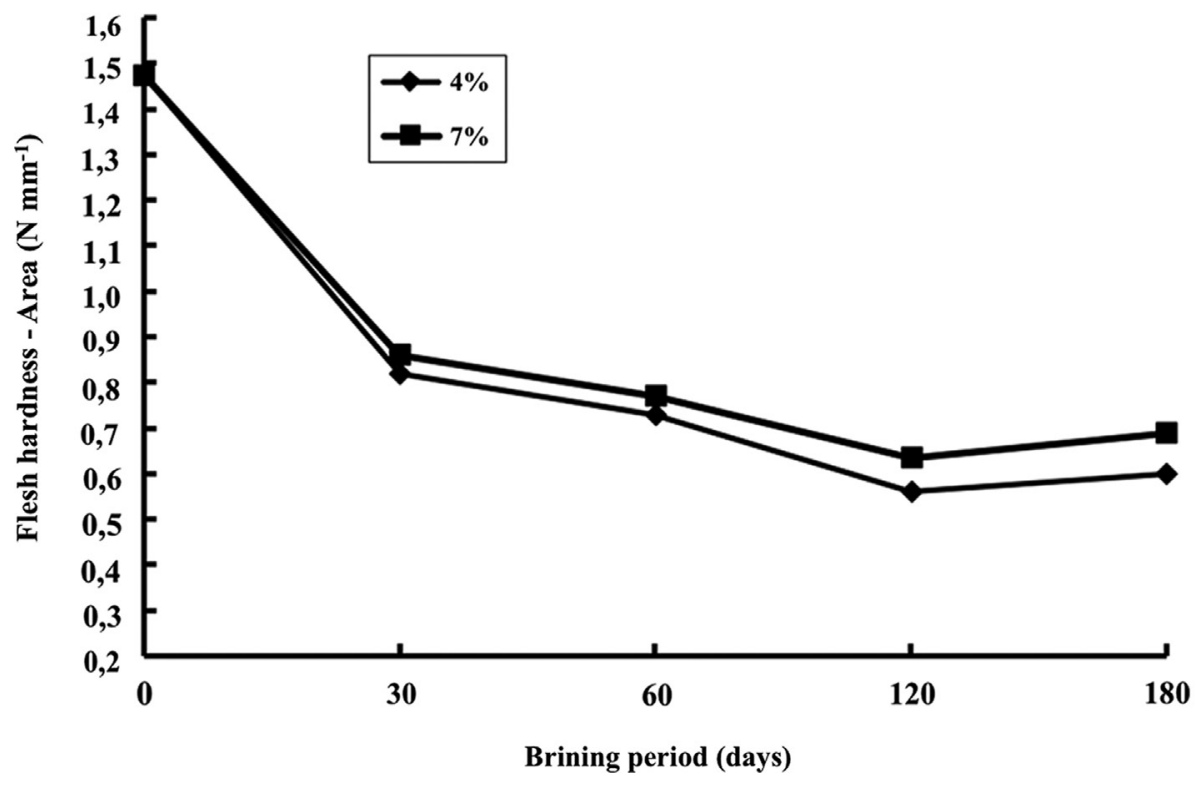

FIGURE 4. Evolution of flesh hardness as revealed by the puncture test during 180 days of brining of "Tonda di Cagliari" table olives.

brining of green table olives using two different sodium chloride concentrations.

\subsection{Antioxidant activity evolution}

The DPPH test is an in vitro radical scavenging (RS) measurement and its evolution during the 180 days of brining is reported in Figure 6 as percent absorbance decrease, with respect to a blank of DPPH without sample, after 60 minutes of reaction. It is worth pointing out that the major loss in RS activity has been recorded after the first month of brining (22-28\%), thus mirroring the polyphenol loss, and that the total loss was close to $40 \%$ (34$42 \%$ ) at the end of processing. A loss in antioxidant activity during brining has been already reported and was found to be well correlated to polyphenol loss (Ben Othman et al., 2009). In our case, the polyphenol loss was higher, accounting for $78-82 \%$ at the end of the brining period, with respect to the decrease in antioxidant activity reported before. Compounds other than polyphenols or polyphenols themselves in an intermediate state of oxidation may be present in the extract, thus explaining the lower decrease in $\mathrm{RS}$, with respect to \% loss in polyphenolic content. Olives brined with $7 \%$ of $\mathrm{NaCl}$ showed a higher RS activity, with respect to the $4 \%$ brined samples, probably due to the higher polyphenol content of the extract.

As stated for texture evolution, no other data are present in the literature concerning the antioxidant evolution during the brining of green table olives by means of two different sodium chloride concentrations.

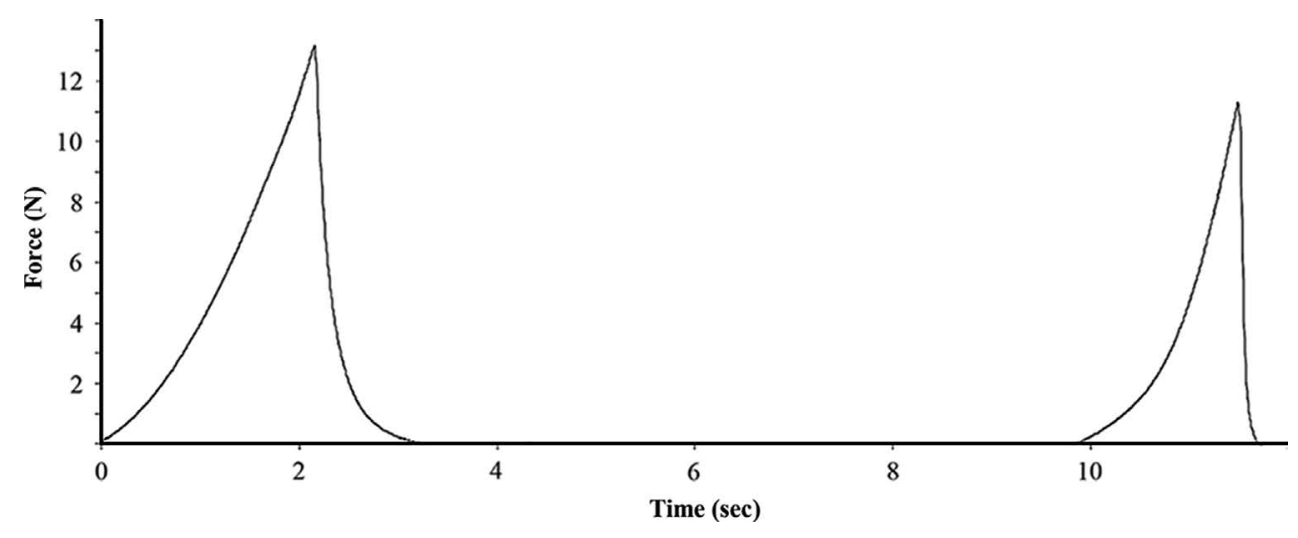

FIGURE 5. Representative graph of the TPA test. 
TABLE 3. Texture* of Tonda di Cagliari brined olives as affected by different brine salt concentrations and storage periods

\begin{tabular}{lccccc}
\hline \multirow{2}{*}{ Source of variation } & \multicolumn{5}{c}{ Texture Profile Analysis Parameters } \\
\cline { 2 - 6 } NaCl (\%) & Hardness $(\mathbf{N})$ & Cohesiveness & Gumminess $(\mathbf{N})$ & Chewiness $_{\left(\mathbf{N} \text { mm}^{-1}\right)}$ & Springiness \\
$\mathbf{4}$ & & & & \\
$\mathbf{7}$ & $29.79 \mathrm{a}$ & $0.378 \mathrm{a}$ & $11.74 \mathrm{a}$ & $22.54 \mathrm{a}$ & $0.622 \mathrm{a}$ \\
& $29.00 \mathrm{a}$ & $0.379 \mathrm{a}$ & $11.42 \mathrm{a}$ & $21.50 \mathrm{a}$ & $0.631 \mathrm{a}$ \\
Sampling period (days) & & & & \\
$\mathbf{0}$ & $56.11 \mathrm{a}$ & $0.438 \mathrm{a}$ & $24.69 \mathrm{a}$ & $53.65 \mathrm{a}$ & $0.732 \mathrm{a}$ \\
$\mathbf{3 0}$ & $22.93 \mathrm{~b}$ & $0.345 \mathrm{c}$ & $7.90 \mathrm{~b}$ & $13.28 \mathrm{~b}$ & $0.589 \mathrm{~b}$ \\
$\mathbf{6 0}$ & $22.97 \mathrm{~b}$ & $0.368 \mathrm{bc}$ & $8.45 \mathrm{~b}$ & $14.58 \mathrm{~b}$ & $0.622 \mathrm{~b}$ \\
$\mathbf{1 2 0}$ & $21.94 \mathrm{~b}$ & $0.381 \mathrm{~b}$ & $8.31 \mathrm{~b}$ & $13.66 \mathrm{~b}$ & $0.595 \mathrm{~b}$ \\
$\mathbf{1 8 0}$ & $23.03 \mathrm{~b}$ & $0.362 \mathrm{bc}$ & $8.54 \mathrm{~b}$ & $14.93 \mathrm{~b}$ & $0.593 \mathrm{~b}$ \\
\hline
\end{tabular}

*Texture has been determined with a TPA test (see the Materials and Methods section).

${ }^{x}$ Data with different letters within each source of variation, thesis and column differ significantly according to the Tukey test at $P \leq 0.05$.

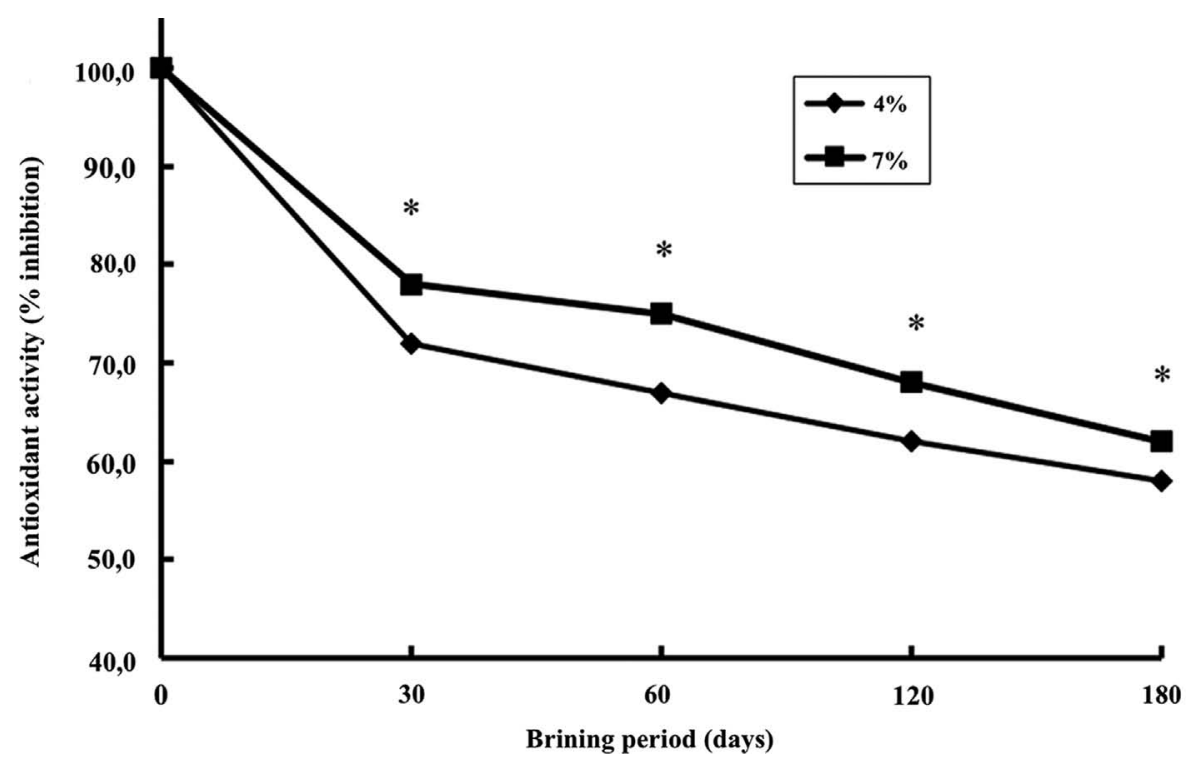

FIGURE 6. Evolution of antioxidant activity of the polyphenolic extract from the flesh of "Tonda di Cagliari" green olives during 180 days of brining. All the values have been normalized considering $100 \%$ as the value of fresh olives. * Means statistically significant means for the same period.

\subsection{Sensory evaluation}

The panellists positively judged both samples, however, 23 judges preferred the olives brined with $4 \%$ sodium chloride, as they found the olives less salty and bitter, with respect to the $7 \%$ brined ones. This result is significant at $P \leq 0.01$.

\section{CONCLUSIONS}

The use of different salt concentrations in the brining of naturally fermented green olives resulted in some chemical-physical, textural, antioxidant and sensory differences. Olives brined with the lower $\mathrm{NaCl}$ concentration maintained a lower polyphenol 
content, antioxidant activity and peel hardness during and at the end of processing, but were preferred by panellists, with respect to the olives processed with the higher $\mathrm{NaCl}$ concentration. Both the texture tests used on the whole olives proved to be suitable to follow the texture evolution during brining of this table olive specialty.

\section{ACKNOWLEDGEMENTS}

This research was supported by Ministero delle Politiche Agricole, Alimentari e Forestali (Mipaf), project title "Ottimizzazione delle tecnologie di trasformazione per l'ottenimento delle olive da mensa ad alto impatto sensoriale e nutrizionale".

\section{REFERENCES}

Abriouel H, Benomar N, Cobo A, Caballero N, Fuentes MA, Pérez-Pulido R, Gálvez A. 2012. Characterization of lactic acid bacteria from naturally-fermented Manzanilla Aloreña green table olives. Food Microbiol. 32, 308-316

Amiot MJ, Fleuriet A, Macheix JJ. 1986. Importance and evolution of phenolic compounds in olive during growth and maturation. J. Agric. Food Chem. 34, 823-826.

Araujo AJ, Labavitch JM, Heredia AM. 1994. Changes in the cell wall of olive fruit during processing. J. Agric. Food Chem. 42, 1194-1199.

Arroyo-López A, Durán-Quintana MC, Romero C, RodríguezGómez F, Garrido-Fernández A. 2007. Effect of storage on the sugars, polyphenols, color, and microbiological changes in cracked Manzanilla-Aloreña olives. J. Agric. Food Chem. 55, 7434-7444.

Bautista-Gallego J, Arroyo-López FN, Durán-Quintana MC, Garrido-Fernández A. 2010. Fermentation profiles of Manzanilla-Alorena cracked green table olives in different chloride salt mixtures. Food Microbiol. 27, 403-412.

Bautista-Gallego J, Arroyo-López FN, López- López A, Garrido-Fernández A. 2011. Effect of chloride salt mixtures on selected attributes and mineral content of fermented cracked Aloreña olives. Lebensm-Wiss. Technol. 44, 120-129.

Ben Othman N, Roblain D, Chammen N, Thonart P, Hamdi M. 2009. Antioxidant phenolic compounds loss during the fermentation of Chétoui olives. Food Chem. 116, 662-669.

Borcackli M, özay G, Alperden I, Ozsan E, Erdek Y. 1993. Changes in chemical and microbiological composition of two varieties of olive during fermentation. Grasas Aceites 44, 253-258.

Bourne MC. 1979. Theory and application of the puncture test in food texture measurement. In Sherman P (Ed.) Food Texture and Rheology. Academic Press, New York/ London, 95-142.

Brenes-Balbuena M, García-García P, Durán-Quintana MC, Garrido-Fernández A. 1986. Estudio comparativo de sistema de conservacion de aceitunas tipo negras. Grasas Aceites 37, 123-128.

Coimbra MA, Waldron KW, Delgadillo I, Selvendran RR. 1996. Effect of processing on cell wall polysaccharides of green table olives. J. Agric. Food Chem. 44, 2394-2401.

Durán-Quintana MC, González Cancho F. 1973. Estudio microbiologico de la fermentacion de aceitunas negras maduras en salmuera. Grasas Aceites 24, 149-159.

Farris GA, Deiana P, Budroni M. 1989. La microflora blastomicetica delle drupe e delle salamoie delle olive da mensa. Ind Aliment-Italy 28, 263-270.

Fernández-Bolaños J, Rodríguez R, Saldaña C, Heredia A. Guilén R, Jiménez A. 2001. Factors affecting the changes in texture of dressed ("aliñadas") olives. Eur. Food Res. Technol. 214, 237-241.
Friedman HH, Whitney JE, Szczesniak, AS. 1963. The Texturometer -A New Instrument for Objective Texture Measurement. J. Food Sci. 28, 390-396.

Garrido-Fernández A, Fernández-Diez MJ, Adams MR 1997. Control methods. In: Garrido-Fernández A, Fernández-Diez MJ, Adams MR (Eds.) Table Olives: Production and Processing, Chapman and Hall, London, 461-479.

Georget DMR, Smith AC, Waldron KW, Rejano L. 2003. Effect of 'Californian' process of Hojiblanca olive (Olea europaea L.) harvested at different ripening stages. J. Sci. Food Agr. 83, 574-579.

González-Cancho F, Nosti Vega M, Durán-Quintana MC, Garrido-Fernández A, Fernández-Díez MJ 1975. El proceso de fermentacion en aceitunas negras maduras en salmuera. Grasas Aceites 26, 297-309.

International Olive Oil Council. 2004. Trade Standards Applying to Table Olives. COI/OT/NC no. 1, Madrid.

International Olive Oil Council. 2012. Olivae. International Olive Oil Council, Madrid.

Jiménez A, Heredia A, Guillén R, Fernández-Bolaños J. 1997. Correlation between soaking conditions, cation content of cell wall, and olive firmness during 'Spanish green olive' processing. J. Agric. Food Chem. 45, 1653-1658.

Kanavouras A, Gazouli M, Tzouvelekis Leonidas L, Petrakis C. 2005. Evaluation of black table olives in different brines. Grasas Aceites 56, 106-115.

Lanza B, Di Serio MG, Iannucci E, Russi F, Marfisi P. 2010. Nutritional, textural and sensorial characterisation of Italian table olives (Olea europaea L. cv. 'Intosso d'Abruzzo'). Int. J. Food Sci. Tech. 45, 67-74.

Malheiro R, Sousa A, Casal S, Bento A, Pereira JA. 2011. Cultivar effect on the phenolic composition and antioxidant potential of stoned table olives. Food Chem. Toxicol. 49, 450-457.

Marquina D, Peres C, Caldas FV, Marques JF, Peinado JM, Spencer-Martins I. 1992. Characterization of the yeast population in olive brines. Lett. Appl. Microb. 14, 279-283.

Marsilio V, Lanza B, Campestre C, De Angelis M. 2000. Oven dried table olives: textural properties as related to pectic composition. J. Sci. Food Agr. 80, 1271-1276.

Medina E, Gori C, Servili M, de Castro A, Romero C, Brenes M. 2010. Main variables affecting the lactic acid fermentation of table olives. Int. J. Food Sci. Tech. 45, 1291-1296.

Morales-Sillero A, Fernández JE, Rejano L, Jiménez R, Troncoso A. 2008. Effect of fertigation on the 'Manzanilla de Sevilla' table olive quality before and after 'Spanishstyle'olive processing. HortScience 43, 153-158.

Moreno-Baquero JM, Bautista-Gallego J, Garrido-Fernández A López-López A. 2012. Mineral Content and Sensory Characteristics of Gordal Green Table Olives Fermented in Chloride Salt Mixtures. J. Food Sci. 77, S107-S114.

Panagou EZ, Hondrodimou O, Mallouchos A, Nychas GJE. 2011. A study on the implications of $\mathrm{NaCl}$ reduction in the fermentation profile of Conservolea natural black olives. Food Microbiol. 28, 1301-1307.

Pereira JA, Pereira APG, Ferreira ICFR, Valentão P, Andrade PB, Seabra R, Estevinho L, Bento A. 2006. Table olives from Portugal: phenolic compounds, antioxidant potential and antimicrobial activity. J. Agric. Food Chem. 54, $8425-8431$.

Piga A, Gambella F, Vacca V, Agabbio M. 2001. Response of three Sardinian olive cultivars to greek-style processing. Ital. J. Food Sci. 13, 29-40.

Piga A, Agabbio M. 2003. Quality improvement of naturally green table olives by controlling some processing parameters. Ital. J. Food Sci. 15, 259-268.

Poiana M, Romeo FV. 2006. Changes in chemical and microbiological parameters of some varieties of Sicily olives during natural fermentation. Grasas Aceites 57, 402-408.

Ramadan MF, Morsel J. 2006. Screening of the antiradical action of vegetable oils. J. Food Compos. Anal. 19, 838-842.

Rejano-Navarro L, Sánchez-Gómez AH, Vega-Macia V. 2008. Nuevas tendencias en el tratamiento alcalino "cocido" de las aceitunas verdes aderezadas al estilo español o sevillano. Grasas Aceites 59, 197-204. 
Rodriguez-Gómez F, Bautista-Gallego J, Romero-Gil V, Arroyo-López FN, Garrido-Fernández A, García-García P. 2012. Effects of salt mixtures on Spanish green table olive fermentation performance. Lebensm-Wiss. Technol. 46, 56-63.

Romeo FV, De Luca S, Piscopo A, Perri E, Poiana M. 2012. Effects of post-fermentation processing on the stabilisation of naturally fermented green table olives (cv Nocellara etnea). Food Chem. 116, 873-878.

Sousa A, Ferreira ICFR, Barros L, Bento A, Pereira JA 2008. Effect of solvent and extraction temperatures on the antioxidant potential of traditional stoned table olives "alcaparras". Lebensm-Wiss. Technol. 41, 739-745.
Stone E, Sidel JL. 2004a. Affective testing. In: Stone E, Sidel JL (Eds.) Sensory Evaluation Practices, 3rd ed. Elsevier Academic Press, London, pp. 262-264.

Stone E, Sidel JL. 2004b. Discrimination testing. In: Stone E, Sidel JL (Eds.) Sensory Evaluation Practices, 3rd ed. Elsevier Academic Press, London, pp. 177.

Szczesniak AS. 1963. Classification of Textural Characteristics. J. Food Sci. 28, 385-389.

Tassou CC, Katsaboxakis CZ, Georget DMR, Parker ML, Waldron KW, Smith AC, Panagou EZ. 2007. Effect of calcium chloride on mechanical properties and microbiological characteristics of cv. Conservolea naturally black olives fermented at different sodium chloride levels. J. Sci. Food Agr. 87, 1123-1131. 